\title{
Analysis of the Solar Radiation Impact on Cooling Performance of the Absorption Chiller
}

\author{
Pavol Fedorčák, Danica Košičanová, Richard Nagy, Peter Mlynár \\ Technical University of Košice \\ Civil Engineering Faculty, Institute of Building and Environmental Engineering \\ e-mail: pavol.fedorcak@tuke.sk, danica.kosicanova@tuke.sk, richard.nagy@tuke.sk, peter.mlynar@stuba.sk
}

\begin{abstract}
Absorption cooling at low power is a new technology which has not yet been applied to current conditioning elements. This paper analyzes the various elements of solar absorption cooling. Individual states were simulated in which working conditions were set for the capability of solar absorption cooling to balance heat loads in the room.

The research is based on an experimental device (absorption units with a performance of $10 \mathrm{~kW}$ ) developed at the STU in Bratislava (currently inputs and outputs of cold sources are being measured). Outputs in this paper are processed so that they connect the entire scheme of the solar absorption cooling system (i.e. the relationship between the solar systems hot and cold storage and the absorption unit).

To determine the size of the storage required, calculated cooling for summer months is considered by the ramp rate of the absorption unit and required flow rate of the collectors.
\end{abstract}

Key words: solar radiation, cooling power absorption unit

\section{Introduction}

As a result of rising energy prices is an obvious effort to use the available alternative source of energy. One of the possibilities of alternative energy production is to use the Sun as an inexhaustible source of energy. Solar energy incident on the Earth's surface can be converted into thermal energy using solar systems. Worldwide, these issues are given large attention. It has been recorded that each summer tends to show an increasing maximum and average temperature compared to the last when viewed over a period of several decades. This has created an increased demand for air- conditioning systems in individual buildings. With the increasing requirements for the comfort indoor environment is drawing more attention to the sorption cooling systems which can be driven by the heat flow with temperature beginning at about $70^{\circ} \mathrm{C}$. The development of the sorption cooler with low-power $(2-20 \mathrm{~kW})$ is a modern subject of research. Up to now, developed absorption refrigeration units with a great power 
from 30 to $6000 \mathrm{~kW}$ were not usable for smaller objects but only for the industrial buildings and the objects of a major character.

\section{Methodology}

This paper specifically considers solar absorption cooling. At the STU in Bratislava, Daniel Čurka developed an absorption unit with a maximum power of $10 \mathrm{~kW}$ as is shown in Fig. 1.

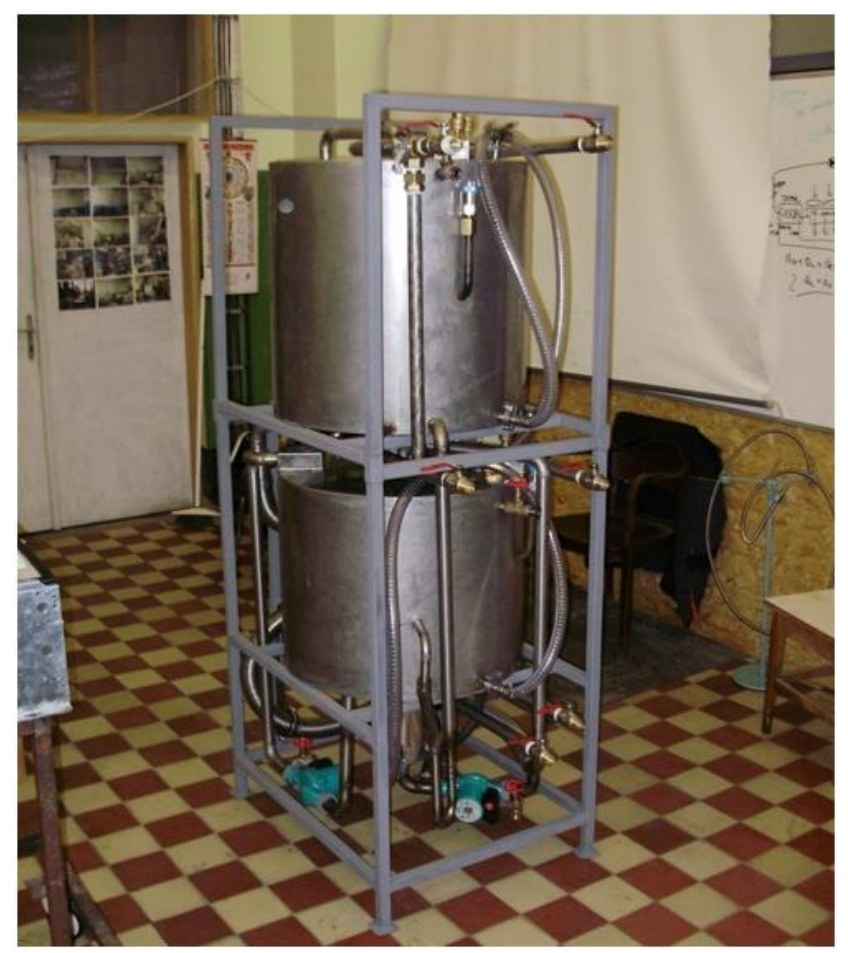

Figure 1: Absorption unit at STU in Bratislava

Experiments were focused on the power input and output parameters of the absorption units, which are incorporated into the scheme of the absorption unit's solar cooling system. This paper quantifies the effect of heat stress in rooms that run absorption units.

\subsection{Analysis of flow determination of the intensity of solar radiation}

To power absorption unit is important temperature and required flow. It is therefore necessary to provide the required flow volume of the necessary temperature difference on the collector tray and storage heat. To calculate the flow, we expect flat plate collectors, flat plate collector's specifically high Logasol SKS 4.0-s.

Fig. 2 shows a schematic diagram of heat flow through the collector. The question is how to calculate the thermal properties, i.e. determine the useful energy gain of the collector. It is therefore necessary to define a step by step each heat flow equation to find the efficiency of a solar system and then determine the required flow. 


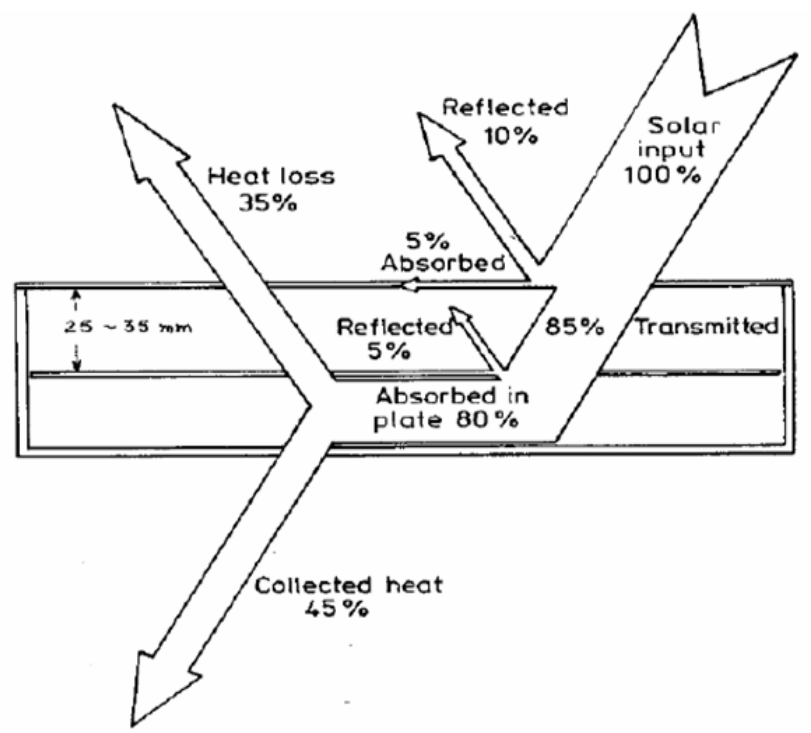

Figure 2: Heat flow solar collector area [1]

Were used to calculate the following formula generally known as the "Hottel - Whillier - Bliss equation" [1].

$$
Q_{u}=F_{r} \cdot A\left[I \cdot(\tau \alpha)-U_{L} \cdot\left(\Theta_{i}-\Theta_{a}\right] \quad[\mathrm{W}]\right.
$$

Where, $F_{r}$ is collector heat removal factor,

$$
\begin{aligned}
& \text { A - collector area }\left[\mathrm{m}^{2}\right] \text {, } \\
& \mathrm{U}_{\mathrm{L}} \text { - overall heat transfer coefficient of the collector }\left[\mathrm{W} \cdot \mathrm{m}^{-2} \cdot \mathrm{K}^{-1}\right] \text {, } \\
& \Theta_{\mathrm{a}} \text { - Ambient temperature }\left[{ }^{\circ} \mathrm{C}\right] \text {, } \\
& \Theta_{\mathrm{i}} \text { - collector inlet temperature in }\left[{ }^{\circ} \mathrm{C}\right] \text {. }
\end{aligned}
$$

A measure of a flat plate collector performance is the collector efficiency $(\eta)$ defined as the ratio of the useful energy gain $\left(Q_{u}\right)$ to the incident solar energy over a particular time period:

$$
\eta=\frac{\int Q_{\mathrm{u}} \mathrm{d} t}{A \cdot \int I \mathrm{~d} t}
$$

The instantaneous thermal efficiency of the collector is:

$$
\begin{gathered}
\eta=\frac{Q_{u}}{A \cdot I} \\
\eta=\frac{F_{r} \cdot A\left[I(\tau \alpha)-U_{L}\left(\Theta_{i}-\Theta_{a}\right)\right]}{A \cdot I} \\
\eta=F_{r}(\tau \alpha)-\frac{F_{r} \cdot U_{L}\left(\Theta_{i}-\Theta_{a}\right)}{I}
\end{gathered}
$$


Heat transfer coeficient $U_{L}$ is not exactly constant, so that we achieve a better term that takes into account the linear dependence versus $U_{L}\left(\Theta_{i}-\Theta_{a}\right)[2]$ :

$$
\eta=F_{r}(\tau \alpha)-\frac{F_{R} \cdot U_{L}\left(\Theta_{i}-\Theta_{a}\right)}{I}-\frac{F_{R} \cdot U_{L}\left(\Theta_{i}-\Theta_{a}\right)^{2}}{I}
$$

Then we can write this equation as:

$$
\eta=a_{0}-\frac{a_{1}(\Delta \Theta)}{I}-\frac{a_{2}(\Delta \Theta)^{2}}{I}
$$

where, $a_{0}$ is the collector efficiency factor,

$\mathrm{a}_{1}$ - heat transfer coefficient layer on the front of the collector $\left(\mathrm{W} \cdot \mathrm{m}^{-2} \cdot \mathrm{K}^{-1}\right)$,

$\mathrm{a}_{2}$ - thermal transmittance of the film on the back of the collector $\left(\mathrm{W} \cdot \mathrm{m}^{-2} \cdot \mathrm{K}^{-1}\right)$.

The instantaneous efficiency of the collector we can express flow rate $\mathrm{m}_{\mathrm{c}}[3]$ :

$$
m_{c}=\frac{3,6 \cdot \eta \cdot I}{c_{p} \cdot\left(\Theta_{i}-\Theta_{a}\right)}
$$

where, $c_{p}$ is heat capacity of liquid $\left(\mathrm{kJ} \cdot \mathrm{kg}^{-1} \cdot \mathrm{K}^{-1}\right), \eta$ - efficiency of the collector,

$\mathrm{c}_{\mathrm{p}}$ - total intensity of solar radiation on tilted collector $\left[\mathrm{W} \cdot \mathrm{m}^{-2}\right]$,

$\Theta_{i}$ - collector inlet temperature in $\left[{ }^{\circ} \mathrm{C}\right]$,

$\Theta_{\mathrm{a}}$ - Ambient $\left[{ }^{\circ} \mathrm{C}\right]$.

From these individual formulas was processed calculation in Excel.

This detail represents only a small part of the processing of all calculations. Using the calculated intensity of solar radiation on the inclined surface of the collector were subsequently addressed depending number of the collectors to the size storage heat while observing the measured values of the absorption unit. Since the measured values of the absorption unit is known at what temperature gradient begins (,, ends") work absorption unit, in this range were selected and the number of collectors and storage size. The size heat storage was set at $700 \mathrm{~L}$, due to the required flow rate $708 \mathrm{~kg} \cdot \mathrm{h}^{-1}$ for the side storage - absorption unit and while with sufficient required temperature for the given number of collectors.

In order to system work and produced enough power absorption unit to the required number of collectors' $\mathrm{min} .9$ of the intensity of solar radiation $780 \mathrm{~W} . \mathrm{m}^{-2}$. Our collector orientation is southeast of inclination $30^{\circ}$.

On the based input $\Theta_{1}$ and output $\Theta_{2}$ temperatures, of the generator and taking into account the flow we determine (compute power generator) (Fig. 3).

$$
Q_{g}=m \cdot c \cdot\left(\Theta_{1}-\Theta_{2}\right)[W]
$$

where, $\mathrm{m}$ is flow rate $\left(\mathrm{m}^{3} \cdot \mathrm{s}^{-1}\right)$,

$$
\mathrm{c} \text { - heat capacity }\left(\mathrm{J} \cdot \mathrm{kg}^{-1} \cdot \mathrm{K}^{-1}\right) \text {. }
$$




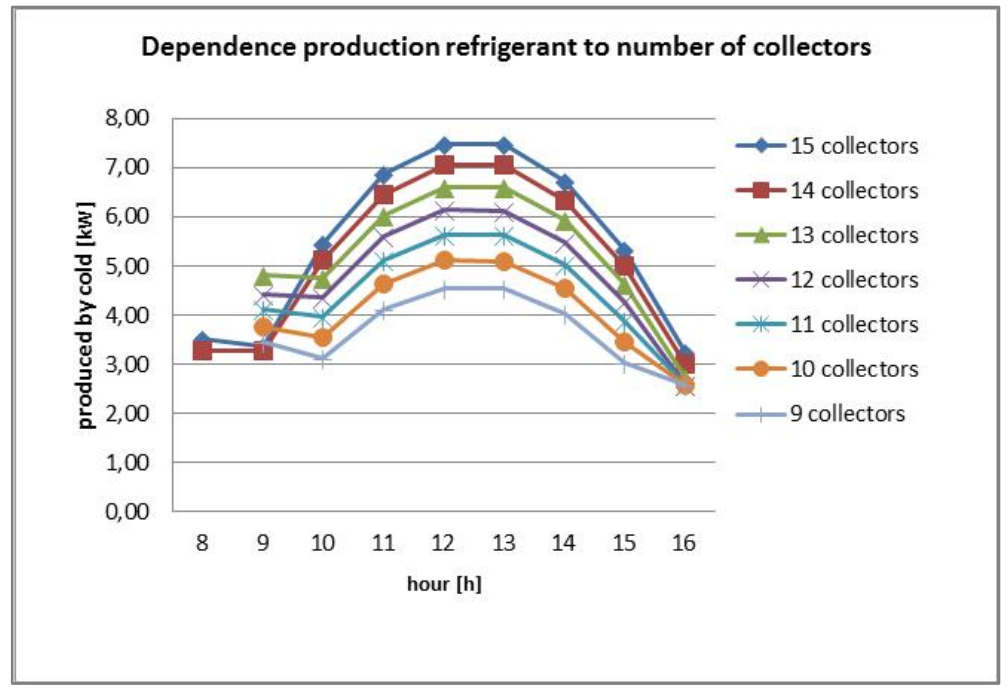

Figure 3: Dependence of power generator on the number of collectors

To determine the storage to cool, it was necessary to choose an experimental room.

\subsection{Experimental room}

An experimental room in a school building was selected to study the influence that ventilation has on the heat load. The classroom, located on the 3rd floor, is a corner room, which has one side of its facade oriented to the southeast, and the second to the north-east. The envelope has a $\mathrm{U}$-value of $\mathrm{U}=1.22 \mathrm{~W} \cdot \mathrm{m}^{-2} \cdot \mathrm{K}^{-1}$, with windows located on both sides of the facade - the old wooden windows have a $\mathrm{U}$ value of $\mathrm{U}=2.8 \mathrm{~W} / \mathrm{m}^{-2} \cdot \mathrm{K}^{-1}$, which are illustrated in are illustrated in Fig.4.

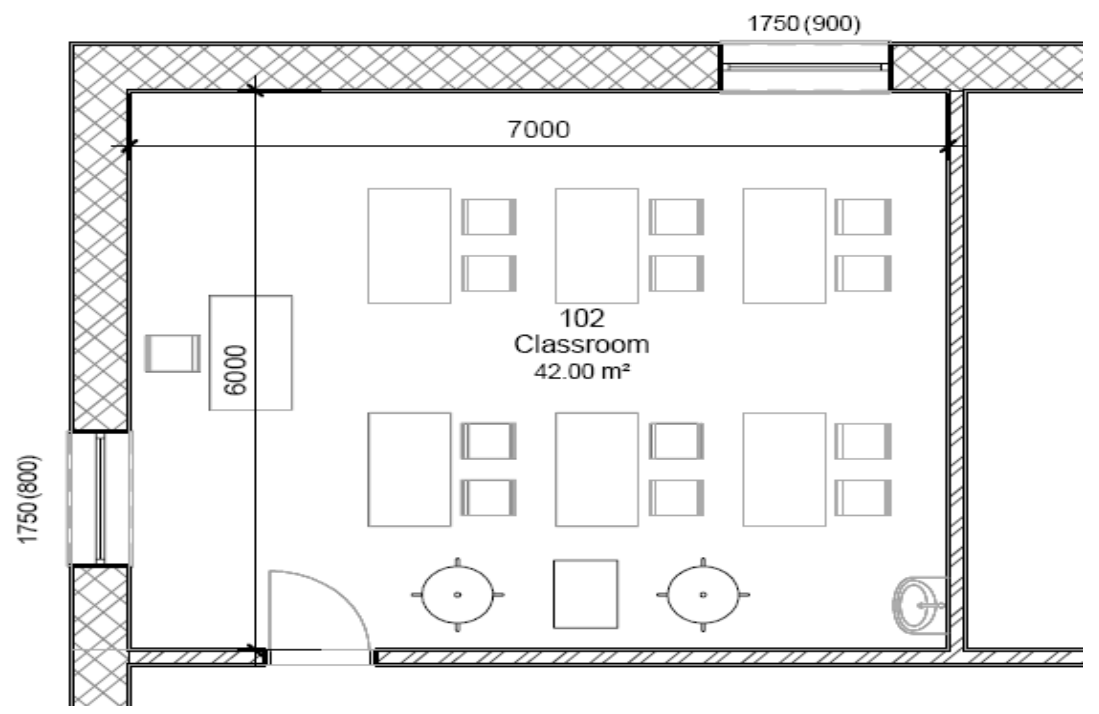

Figure 4: Floor plan of experimental space 
In this room was calculated heat load (in $21^{\text {th }}$ July) in the simulation program Simulace 2009 as shown in Fig. 5. Then using the heat load was designed air conditioning unit (Fig.6).

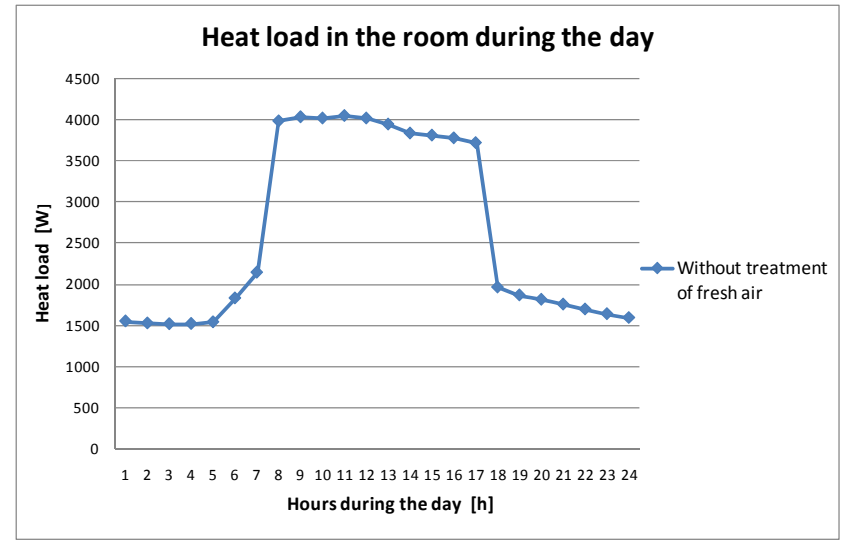

Figure 5: Heat load in the room during the day

A LG Libero E + E12SQU E12SQ inverter with a 4kW cooling capacity was installed in the room above.

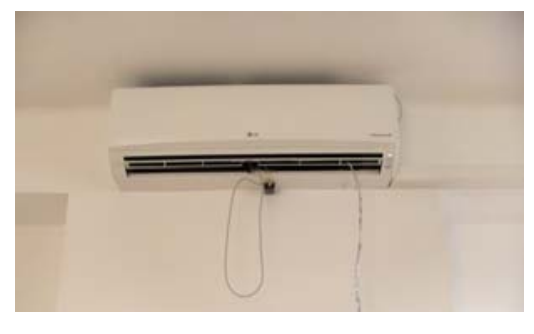

Figure 6: LG unit positioned in the experimental space

The internal unit was installed in order to measure the cooling load required in the room during the day. The unit does not contain built-in software that would evaluate the cooling load of each hour during the day. Therefore, temperature gauges were installed at predetermined locations. Temperature sensors 1 and 2 were placed on the internal unit; one on the air inlet and the second on the air exhaust duct. Temperature sensor number 3 was placed in the center of the room and was designed to sense indoor air temperature beside a seated occupant at a height of $1.05 \mathrm{~m}$ as shown in Fig.7.

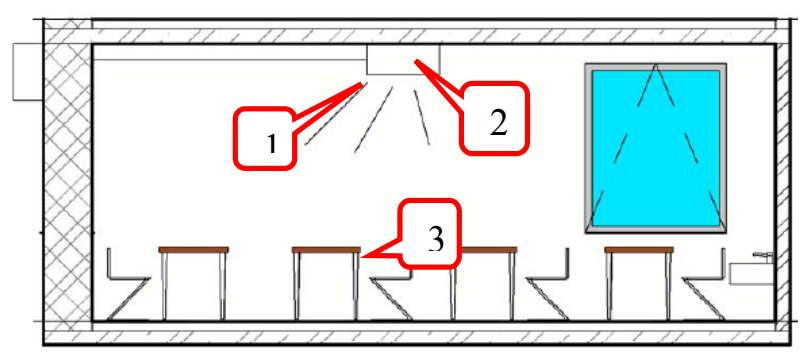

Figure 7: Position of sensors 
The indoor unit has three power levels at intervals of $4,8,12 \mathrm{~m}^{3} \cdot \mathrm{min}^{-1}$. The third power level of $12 \mathrm{~m}^{3} \cdot \mathrm{min}^{-1}$ was selected.

Since airflow (P) is known, the temperature at input $\left(\Theta_{1}\right)$ and outlet $\left(\Theta_{2}\right)$ of the unit can predetermine the cooling load $\left(\mathrm{Q}_{\mathrm{ch}}\right)$.

$$
\mathrm{Q}_{\mathrm{ch}}=\mathrm{m} \cdot \mathrm{c} \cdot\left(\Theta_{1}-\Theta_{2}\right)[\mathrm{W}]
$$

Where, $\mathrm{c}$ is heat capacity of air $\left(\mathrm{J}_{\mathrm{kg}} \mathrm{kg}^{-1} \cdot \mathrm{K}^{-1}\right)$,

$\mathrm{m}$ - mass flow rate, which should be expressed as:

$$
\mathrm{m}=\rho \cdot \mathrm{V} \quad\left[\mathrm{kg} \cdot \mathrm{s}^{-1}\right]
$$

Where, $\rho$ is air density at a given temperature in $\left(\mathrm{kg} \cdot \mathrm{m}^{-3}\right)$, which at a room temperature of 25 ${ }^{\circ} \mathrm{C}$, an air density of 1.1845 is recorded.

The room will be thermally stressed by 13 occupants as a result of heat gains due to convection and additionally by solar radiation and fresh air. The selected classrooms were occupied from 8:00 to 18:00. To ensure uniform operation of the room, the heat output from the occupants were replaced by a heater with a power of $800 \mathrm{~W}$. This output represents 13 occupants, based on a $60 \mathrm{~W}$ sedentary condition of a sitting occupant.

Each measurement took place at the end of August 2012. The outside air temperature during individual measurements reached $31^{\circ} \mathrm{C}$.

Room temperature at 7:30 am was approximately $27^{\circ} \mathrm{C}$. In order to achieve a temperature of $26{ }^{\circ} \mathrm{C}$ before the arrival of the "occupants" expected at 8:00 am, it was necessary to start cooling the room at 7:30. The air conditioner was set to maintain a room temperature of $24{ }^{\circ} \mathrm{C}$, at maximum power i.e. $12 \mathrm{~m}^{3} \cdot \mathrm{min}^{-1}$.

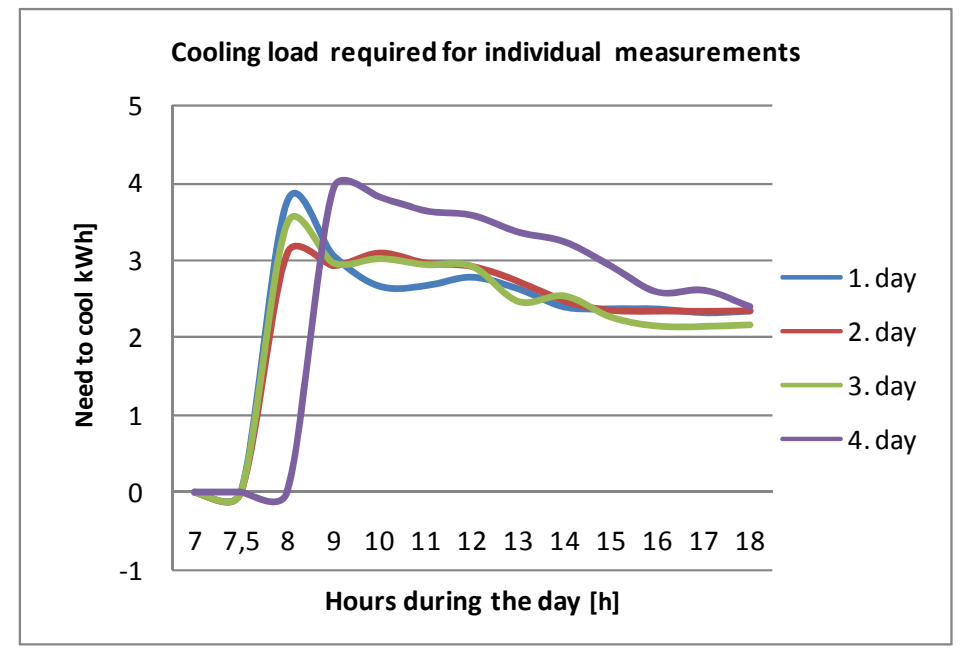

Figure 8: Cooling load required for individual measurements

Fig.8 shows the required cooling load of the room during each measurement day. On this graph we can see that the need for cooling is highest from 7:30 to about 10:00 am. This is due 
to the orientation of the room which is southeast / northeast, resulting in morning solar gains through the glazing. Another cause is the accumulation of heat in the walls, which radiate heat into the room. Moreover, the arrival of students into the room at the start of cooling creates the largest cooling demand in the morning.

Recorded data was evaluated with the aid of measuring equipments which were installed in the experimental room. We obtained the course of cooling requirements for each hour daily, i.e. the behavior of the room during the day while subjected to cooling. This important information is required when sizing a solar absorption cooling assembly. These simulations were conducted to determine the number of collectors and solar radiation intensity required, for the absorption refrigeration unit to effectively cool the room.

\section{Results}

Individual simulations were designed for days that were measured in the experimental room starting at the end of August beginning of September. Since the measured values at which the temperature gradient of the absorption unit begins (,, ends'") are known, the number of collectors and storage size could be determined. The hot storage tank size measured $700 \mathrm{~L}$, due to a required flow rate of $708 \mathrm{~kg} \cdot \mathrm{h}^{-1}$ of the - absorption unit when the temperature is sufficient for a given number of collectors. Simulation conditions were for 9, 10, 11, 12, 13, 14 and 15 collectors.

The Fig.4 illustrates the quantity of cold absorption units with different numbers of collectors. The number of collectors is dependent on the cooling load required for the room, respectively to cover the heat load.

Another important parameter for solar absorption cooling is the time of operation. The absorption unit was in operation from approximately 8 and 9 AM until 16:00. Operation outside this period is used for cold storage. The Fig.9 illustrates the dependency of accumulation in relation to the number of collectors.

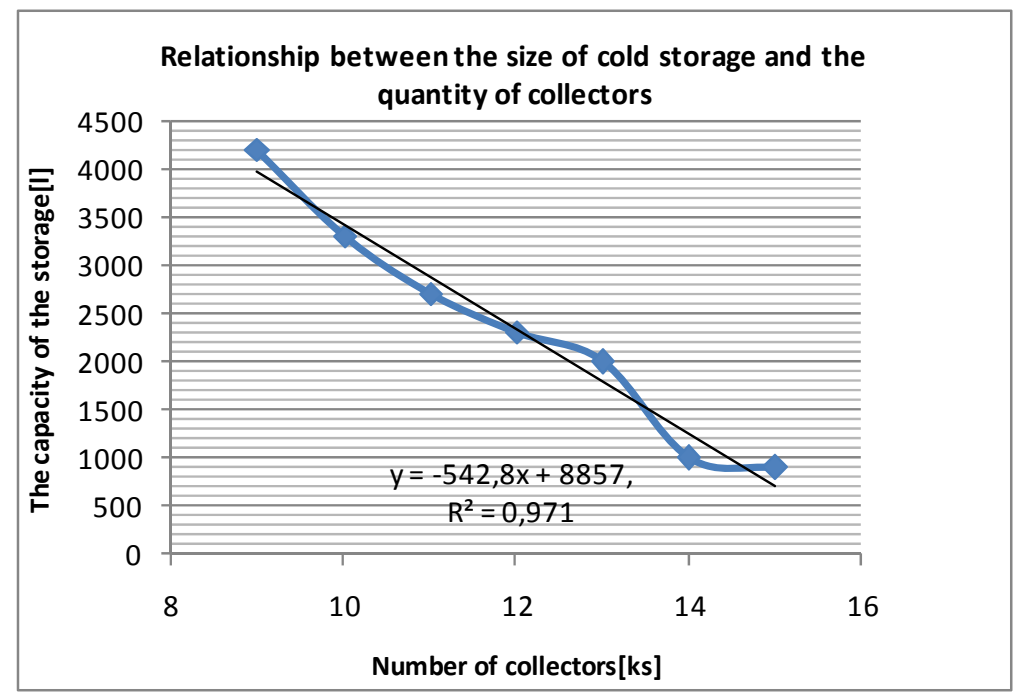

Figure 9: Relationship between the size of cold storage and the quantity of collectors 
A linear equation was developed to calculate the size of the tank with the highest accuracy and $\mathrm{R}^{2}=0.971$ :

$$
y=-542.8 x+8857
$$

Where, $\mathrm{y}$ is the volume of the container

$\mathrm{x}$ - number of collectors

From Fig.9 it can be seen that with an increasing number of collectors the size of cold storage required decreases. The volume decreases from 3000 to $1600 \mathrm{~L}$. This result, as mentioned above in a lower temperature made available to the evaporator, cold storage or directly to the cooling unit. The size of the storage tank used depends on the cooling load and on the available area where the tank is to be located.

\section{Conclusion}

Solar cooling offers an important opportunity to tackle climate change, to reduce emissions of greenhouse gases and proliferation. Using absorption unit with an output of $10 \mathrm{~kW}$ and a suitable design of the components in this diagram we can cover the heat load in smaller premises such as offices, houses etc. Individual above relationships was calculated intensity of solar radiation at the impact on the inclined plane of the collector per hour in Slovakia. In the research of solar cooling is used with the need for cold months from about May until September. Determine the dependence of the intensity and impact of solar radiation on the accumulation of hot water and heat gained the power absorption unit. The individual measured value of absorption units was used in determining the number of collectors and the storage tank to heat. It was expressed various flow rates and temperatures for different numbers of collectors and determine the resulting cooling capacity of the absorption unit.

\section{Acknowledgements}

This work is directly related to the solution of the scientific project VEGA $1 / 07 / 48 / 11$, Theoretical and experimental analysis of system techniques in connection with environmental pollution and the efficient use of renewable resources" and KEGA 052TUKE-4/2013 Project Title: "Use of virtual laboratory for designing energy-efficient buildings".

\section{References}

[1] Fabio Struckmann. (2008). Analysis of a Flat - plate Solar collector. Lund University Sweden, MVK160 Heat and Mass Transport.

[2] Simulation program Trn sys 16 documentation - 05 Mathematical Reference,5.10.1 Type 1Flat plate Collector ( Quadratic efficiency), s.333-337

[3] Simulation program Tran sol EDU 3.1/Interface: solar system components - solar collectors.

[4] Vilčeková, S., Sedláková, A., Krídlová Burdová, E., Čuláková, M., Geletka, V., Kapalo, P. (2013). Analysis of Environmental Aspects in High Energy Performance Family House - Case Study. Chemical Engineering Transactions. Vol. 35 pp. 385-390.

http://www.scopus.com/record/display.url?eid=2-s2.0-

$84886380446 \&$ origin $=$ resultslist $\&$ sort $=$ plf-f\&src $=\mathrm{s} \& .$. 
[5] Sedláková, A., Vojtuš, J., Krídlová Burdová, E. (2012). Concept of building structure design and environmental assessment for consumer model of research in order to force the integration of renewable energy sources,. In: 9. International Scientific Conference FCE TUKE : The 35th Anniversary of the Faculty of Civil Engineering and The 60th Anniversary of the Technical University of Košice : 22. - 25.5.2012, Košice. - Košice : TU, pp. 1-8.

[6] Azariová, K., Horbaj, P., Jasminská, N. (2010). Zníženie energetickej náročnosti budov, 2010. In: EKO - ekologie a společnost. Vol. 21, no. 3, pp. 27-28.

[7] Tauš, P., Kudelas, P. (2013). Evaluation of the solar collectors operational parameters, 1. vyd Ostrava: VŠB-TU.

[8] Jasminská, N., Azáriová, K., Brestovič, T. (2013). System for calculating and modeling the options to improve the energy efficiency of the building, 2013. In: Construction of optimized energy potencial. Vol. 12, no. 2, pp. 21-30.

[9] Brestovič, T., Jasminská, N., Čarnogurská, M., Puškár, M., Kelemen, M., Fil’o, M. (2014). Measuring of thermal characteristics for Peltier thermopile using calorimetric method / Tomás Brestovič ... [et al.]. In: Measurement. Vol. 53, pp. 40-48. http://www.sciencedirect.com/science/article/pii/S0263224114001225...

[10] Kušnír. M., Vranay, F., Kapalo, P.: Synergia progresívnych sústav techniky prostredia a obnovitel'ných zdrojov energií, 1. vyd. - Košice : TU - 2013. - 116 s.- ISBN 978-80-553-1506-5. 